will be eaten by some of the family. This view also will be challenged by some British authorities. Nor should we forget the importance of the way in which food is served. The effects, for example, of the method of serving it on individual plates are discussed by the Committee on Food Habits, and all of us have probably suffered-or benefited-from the system of training children to eat up what is on the plate, without adequate consideration of what the physiological or mental results may be.

In a leading article in the same issue (p. 47), The Lancet gives the salutary reminder that it was not science that made our forbears healthy on the food which they liked; science only enables us to understand why they were healthy. The primary error that we have made, says Mr. F. Le Gros Clark (also in the same issue of The Lancet, p. 55), is that of looking upon food habits as a health problem. To the public, milk, for example, is a beverage, and we have almost succeeded in converting it into a medicine. Neither Lord Horder nor Mr. Le Gros Clark is, of course, seeking to belittle the value of scientific knowledge about food; they are both, like the United States Committee on Food Habits and the British Food Education Society, concerned to create a gradual and irreversible change in food preferences ; but the views of Lord Horder and Mr. Le Gros Clark will be welcomed for their practical common sense.

The study of the influence of methods of preparation of foods leads the inquirer into many complex problems. The Lancet (542, April 22, 1944) has pointed out, in a discussion of a memorandum on hospital diet issued by King Edward's Hospital Fund for London (1943), that the hospital ward offers an unparalleled opportunity of giving people experience of the value of rightly chosen and properly prepared food. The King's Fund memorandum lays down the principle that the food service of a hospital should be one of its essential remedial services; and most of us will agree. The remarkably good recipes for war cookery issued in Great Britain by the Ministry of Food and other agencies during the War have taught the people a great deal about the choice and preparation of meals which are both adequate and appetizing. Lord Horder, in his address to the Food Education Society last June (see The Lancet, 53, July 8, 1944), has reminded us that the science of nutrition is a young one and that we should not strain too far the few facts of which we seem certain. Balance the day's diet, by all means, he says, but it is not necessary to balance the individual meal. He also said wise things about white and other kinds of bread.

The many other questions raised by the American report cannot be discussed here. It is already possible, says Miss Mead, to predict the general lines which resistance to, or acceptance of, proposed changes in food habits will follow; but recommendations of methods have to be related to the whole complex of the War and to the cultural, social and individual ideas about food of a variety of peoples. She suggests that, during the War and the immediate post-war period, two tasks must be tackled. One is to maintain the health of the people by the skilful use of existing food supplies; the other is to present the increased knowledge about the use of foods in such a way that it does not become associated with wartime deprivation and therefore is not rejected later on. The additional long-term task, in the United States, is to alter American food habits so that they are based upon a tradition which embodies science and yet are sufficiently flexible to incorporate new scientific results. Altered production and distribution of foods will not by themselves effect this. Nor will authoritative pronouncements effect it, for they tend to breed regional conformity rather than intelligent flexibility. The responsibility rests on those individuals who plan what others will eat. New knowledge must therefore be conveyed to the woman on the farm, in the village and in the city. Mr. Le Gros Clark (loc. cit.) would seek the point at which social preferences are most readily influenced, and suggests that the school canteen, aided by committees of parents, could be developed gradually into an institution for the education of public tastes. The pressing need, writes Miss Margaret Mead, is for the integration of the techniques which have been devised for dealing with various aspects of these problems.

\section{ENGLISH AGRICULTURE, NOW AND AFTERWARDS}

(1) The Farm in the Fen

By Alan Bloom. Pp. $192+20$ plates. (London : Faber and Faber, Ltd., 1944.) 10s. 6d. net.

(2) This Farming Business

By Frank Sykes. Pp. $160+8$ plates. (London : Faber and Faber, Ltd., 1944.) 8s. 6d. net. ORTUNATELY for the countryside of England,
there have always been men who have felt the urge to reclaim heaths, moors and wastelands and bring them into agricultural use. Reclamation went on vigorously during the Napoleonic Wars, during the War of 1914-18, and during the present War ; it has hitherto been essentially an emergency activity. Unfortunately, a great deal of the land thus brought into cultivation has been allowed to go derelict again, so that the whole of the capital embarked has been lost. Reclamation on the grand scale has been undertaken during the present War and a fascinating account of one of these enterprises has now been published.

Mr. Alan Bloom is a born reclaimer. $\mathrm{He}$ began as a nurseryman producing flowering plants for gardens, and having had difficulties owing to dryness of his soil, he looked out for a fen-land farm to which he might transfer the moisture-loving varieties. In 1939 he found a farm in the Burwell Fen which was certainly not short of water; it had, however, been badly run down. Next to it lay Adventurers Fen, which, though at one time cultivated, had long since been abandoned, and had reverted to a water-logged waste. It was a familiar story. Until recently, drainage had been the responsibility of a number of small local bodies, none of them possessing resources or power to do the work properly; as the farms fell in value, so their resources dwindled and less and less drainage could be attempted. Seeing the hopeless- 
ness of the situation, some of the owners leased out their land to turf diggers, who left the surface so badly pitted and lowered that any faint chance of restoration to agriculture vanished.

Mr. Bloom was fortunate in beginning work in 1939 , when the threat of war compelled the Government to increase the output of food. Hís financial difticulties disappeared when the War Agricultural Executive Committee not only ensured the proper drainage of his farm of two hundred acres but also appointed him its agent to reclaim another two hundred and eighty. six acres of Adventurers Fen.

Mr. Bloom has a keen sense of detail and describes vividly the draining and the ditching; the work was not without danger, and, indeed, one man lost his life through the caving in of peat and mud, which engulfed him; a horse also was lost and two tractors only narrowly escaped. The removal of the water was followed by the clearing of the scrub growth and by such levelling as was possible. The land was then ready for ploughing, but another dificulty was met: buried in the fen just below the surface were numbers of oaks, ranging up to $50 \mathrm{ft}$. or more in length, and, of course, very heavy. Much labour and ingenuity were expended in getting these out. Finally the land was sutt.ciently friable to allow of cultivation.

The crops grown were wheat, sugar beet, potatoes and smaller areas of peas, feeding linseed, buckwheat, etc. Only little grass could be kept for the cattle. The soil lacks phosphate, which so far cannot fully be supplied; it shows signs of manganese deficiency; it would be interesting to know whether there is a copper deficiency as in somewhat similar soils in Holland and North Germany.

In the end a considerable amount of food was produced; it was so badly needed that the cost did not matter. The land, too, is back into proper shape for farming, though, of course, it will always need precautions against weeds, against wind erosion, and against flood and fire. But, as stated above, this kind of thing has been done before. Will Adventurers Fen revert once more to the wild after this War is ended, and the great cost of reclamation simply be lost? The difficulties of keeping reclaimed land in cultivation were ably discussed by Dr. C. S. Orwin some years ago in his account of the reclamation of Exmoor forest. They are great, but they are not insurmountable, and it is devoutly to be hoped that the prodigious amount of labour and money expended in land reclamation during these past few years will not be wasted.

The second book on our list is also a record of splendid achievement in food production, but in very different circumstances. Mr. Sykes, like Mr. Bloom, came new to farming and proved to have a great flair for it. In 1927 he took over the tenancy of 1,200 acres of corn- and downland near Salisbury. Prior to 1914 it had maintained four flocks of sheep and employed a staff of twenty men; then during the War years of 1914-18 there had been much ploughing up and corn growing: the productivity ultimately fell so much that the farm had to be abandoned. Mr. Sykes began by laying it down to grass on which he kept Cheviot ewes and dairy heifers and so was able to make a living for himself and the few men still retained. Later he took another similar farm. By 1935 prices were recovering and he was able to improve his system: he had been impressed by what he had read about the advantages of breaking up and reseeding pastures; he tried the method and found that it succeeded. So he decided to adopt ley farming, and as the natural conditions are suitable he has been able greatly to increase his output of food in consequence.

Mr. Sykes briefly but ably summarizes his methods, and the book is a valuable guide to any young farmer on chalk soils. For seeding the ley he uses a mixture of Aberystwyth rye grass (16 lb. per acre $S 23$ ) and white clover (2 lb. $S 100)$ on good land, while for poor hill land he adds $5 \mathrm{lb}$. per acre cocksfoot. He grazes the herbage in the first year and cuts it for hay in the second; he ploughs up directly there is any sign of the appearance of turf. This is done in autumn, and wheat is sown immediately without any break for a bastard fallow, of which he does not approve. A good crop can be obtained relatively cheaply-about $£ 2$ per quarter at present prices. But a second crop of wheat on the same land costs much more to produce, and Mr. Sykes brings out clearly the steep rise in cost as the output of wheat is increased. Like many other farmers, he wishes there was a good autumn barley. He has considerable faith in flax, but not much in sugar beet which, in his view, could never stand against sugar cane in free competition. Potatoes he regards as a crop for the specialist, owing to the extent to which it is becoming mechanized; market-garden crops are beginning to interest him, but he prefers to say little about them at present.

Mr. Sykes sets out his views on the future of British farming. The present enormous output of food from our farms is, of course, being achieved regardless of cost: Mr. Sykes states that the only business part of farming now is filling up forms and keeping the Inland Revenue at arm's length. But it will not always be so, and before long the cry will be for cheaper food. Mr. Sykes admits that we could not completely feed ourselves so cheaply as we could import the food, but he thinks that wheat production at some level between pre-war and present output could be maintained at a contract price of $50 \mathrm{~s}$. per quarter, the wage-rate being as at present. But the British corn-grower cannot stand up against the competition of soil exploiters, or of subsidized imports.

Milk is likely to remain one of the leading farm products, and Mr. Sykes has much to say about its production in greater quantity, in cleaner state, and at lower cost. The present a erage annual output per cow he puts at 400 gallons, but this could be greatly increased; ,000 gallons is not an uncommon yield. The trouble is that milk yield is inherited from the sire, and few recorded sires are available. If artificial insemination were adopted much better use could be made of them. He has much to say about the working of the 'clean milk' campaign, tuberculin testing, attested and accredited herds, etc. On individual farms improvement has been effected, but the con. sumer (who paid the cost) gained little because unclean milk got mixed in during transport. Three diseases, tuberculosis, mastitis and contagious abortion, play havoc with our dairy herds, and he puts the average life of the dairy cow in the milking herd at only two or three years. (The usual figure is higher.) Widespread improvement is di cult because 'reactors' are often sent to market and bought by some other dairy farmer looking for a 'bargain'. One of the great advantages of dairy farming is that it is well suited to the small farmer-and England is and always has been a land of small farms.

Ley farming would also improve our capacity for lamb production, and it should be possible to carry one ewe to the acre. On the other hand, Mr. Sykes 
is not sure that our pre-war output of poultry and eggs can be maintained at anything like pre-war prices. The conditions were rather special and may not recur. Our farmers were guaranteed 45s. per quarter to produce wheat. But foreign wheat was coming on to the market at much lower rates. $\mathrm{Mr}$. Sykes states that French wheat, for which the French Government had paid the French peasant $60 s$., was sold in England at 18s. per quarter. Much of it was bought by poultry-keepers and converted into cheap eggs. However, with more folding of poultry on the farms, and better arrangements for collecting, grading and storing the eggs, Mr. Sykes thinks that a good and regular supply of poultry products can be assured.

Mr. Sykes is no advocate of self-sufficiency, but he considers that imports should be controlled by an import board. Under this would function production boards for the different farm products on which would be represented producers, retailers and consumers : these boards would fix prices and production levels, improve the quality and the marketing of the products. A national marketing board would correlate their work. He does not, however, wish to see the War Agricultural Committees continue in existence, still less does he want control by oificials. The poor farmer must obviously be eliminated, but this will proceed automatically if the production boards insist on adequate standards of quality : to these the poor farmer never could conform.

The book is refreshing and full of good points. A few slips in the chapter on manuring should be corrected if another edition is printed.

A word of praise is due to the publishers, who in spite of war-time difficulties have presented both books in very attractive form and furnished some admirable illustrations.

E. JoHN RUSSELL.

\section{ECONOMIC STUDY OF PLANNING}

The Road to Serfdom

By F. A. Hayek. Pp. viii+184. (London: George Routledge and Sons, Ltd., 1944.) 10s. $6 d$. net.

THERE are some who regard this War as liable to become economically a war against the middle class, as indeed the War of 1914-18 was as touching the middle classes in Germany. Even were this the case I do not know that it would greatly awaken my sympathy. By their chauvinistic short-sightedness they have 'asked for' their own extinction. They correspond to the national phase in human development. They made the National State and will perish with it. However, Prof. Hayek undertakes to show us the way by which they and others will travel to that total servile State, which he, along with Dr. Friedmann, sees as the next phase.

Prof. Hayek does an excellent piece of work on the analytical side. Primarily an economic study of what is involved in 'planning for all', it has some of the sombre quality which distinguished Otto von Seeck's great study of 'the rotting away of the best' at the time of the middle Roman Empire. The aristocratic quality of liberty, such as Signor Croce applauds, is at a discount. Prof. Hayek reminds Englishmen of their own distinctive tradition in which they have now lost confidence. He quotes Milton : "They who seek nothing but their own just liberty have always the right to win it". Milton adds, "wherever they have the power". He indicts Profs. Laski, Mannheim and Carr as "the totalitarians in our midst", and he doubtless would add other names such as those of Messrs. Crowther, Haldane, Bernal, Strachey et al. Economically Prof. Hayek points out that planning of production means planning of consumption and of "the means of all our ends"; that when a man's life is so planned he loses his economic liberty, not sometimes, as under capitalist unemployment, but always. When material life is controlled, as the Socialists also have said, political liberty is an empty name. John Smith is one forty-millionth of a sovereign and one whole slave. The abstract rule of law departs and the tyrannous 'rule of men', the Hitlerite-Stalinist administrative State, arrives, in which law is subject to considerations of particular effects, raison d'etat and bureaucratic convenience. Instead of a man planning his own life, it is planned for him (so much more 'eificiently') by the State. $\mathrm{He}$ is allocated a 'status', as in the later socialist days of the Roman Empire. As, indeed, Aristotle said was inevitable, "a democracy may set up the most complete despotism imaginable".

Where Prof. Hayek, Dr. Erich Fromm, Peter Drucker and (if I may mention him in the same breath) Prof. Mannheim are weak is on the constructive side. Prof. Hayek agrees with the Marxists that planning must be all or nothing. He therefore wants laisser-faire and recognition of "money as one of the greatest instruments of freedom". In Prof. Mannheim's middling position that we can "plan for freedom", he sees only words. I have objected to this Marxist 'die-hardism', and I agree no more with Prof. Hayek or with Mr. Belloc, whom he cites. His is the old argument of Locke (and Hegel) that private property is morally necessary, for those who have got it, as a 'defence of personality'. This is very true but not true enough. Those who control the economic plan can persecute, even to death by starvation"who does not obey shall not eat"; yet the final liberty remains spiritual and includes the power to refuse co-operation. The point is more than academic. It is being demonstrated by Gandhi to-day, and by the Danes on strike in Copenhagen. It is true that Gandhi only confronts the British Raj, full of Victorian moral inhibitions, and not the tyranny of the modern totalitarian State; but the same methods would probably apply.

The mass of men tolerate more readily death in war than unemployment. There is nothing fine in unemployment. It may well be true, as Dr. Fromm suggests, that the mass of men (perhaps unlike the American pioneers) far prefer security to liberty, of which they are no little afraid. The record of history seems to bear this out. It may be bad for progress that this should be so, but progress was always, as Mill said, of a few. If, however, we decide deliberately to move for a civilization less dominated by large-scale heavy industry and more by peasant farming, then the quite inevitable tendency in machine industry to plan for security will be thrust into a more proper perspective against the freedom of the small owner. The real enemy here lies in war, with its tendency to subordinate all to totalitarian planning, even architecture, even child-bearing. Conversely we discover the imperative necessity for liberty of peace -not this or that political gadget but, as Gandhi has insisted, actual peace-shall we say the flat refusal in the future to fight either the U.S.A. or the U.S.S.R. ? The Master of Balliol has described the prescription of Prof. Hayek and those who think with him as the certain recipe for revolution. Man, 